\title{
AN OPTMIZED PROTOCOL FOR SIMULTANEOUS EXTRACTION OF DNA AND RNA FROM SOILS
}

\author{
Rodrigo Costa; Newton C.M. Gomes; Annett Milling; Kornelia Smalla*
}

Federal Biological Research Centre for Agriculture and Forestry (BBA), Braunschweig, Germany.

Submitted: September 15, 2003; Approved: July 05, 2004

\begin{abstract}
In this work we report an optimized protocol for simultaneous extraction of DNA and RNA from soil matrices. Treatment of soil matrices with ethanol followed by bead-beating worked as a successful strategy to lyse the cells without considerable degradation of nucleic acids, resulting in DNA and RNA of good yield and integrity. The reverse transcribed RNA could be amplified with primers targeting a glutamine synthetase $(g \ln A)$ gene fragment. From both DNA and cDNA, 16S rDNA fragments were amplified and analyzed by Denaturing Gradient Gel Electrophoresis (DGGE). The method was applied to soil and rhizosphere (strawberry and oilseed rape) samples. Two other protocols for the extraction of nucleic acids from soil were applied to the same set of samples in order to compare the methods in terms of efficiency and reproducibility. The DGGE profiles indicated no relevant differences between the patterns obtained. The method described here is suitable for rapid processing of many samples and therefore appropriate for ecological studies.
\end{abstract}

Key words: RNA extraction, nucleic acids, rhizosphere, microbial communities

\section{INTRODUCTION}

Microbial community fingerprinting methods based on the extraction of nucleic acids followed by PCR amplification of 16S/18S rRNA genes have been used extensively to assess the microbial structure and diversity of environmental samples $(3,5,7,9,10,12)$. However, conclusions on the metabolically active members of such communities can hardly be drawn since the approach focuses on total extracted DNA as a target for PCR amplification. To overcome such limitations, RNA extraction protocols have been developed as an attempt to gather a better picture of the microbial fraction responsible for productivity in natural systems $(2,4,6,8,11,15)$. RNA is supposed to be an indicator of the fraction of active microbes. Nevertheless, due to the stability and abundance of RNases as well as to the short life-time of mRNA, methods for an unbiased RNA extraction are still not so well developed as the traditional protocols for DNA extraction. Indeed, the establishment of procedures which allow (a) simultaneous extraction of both DNA and RNA, (b) rapid processing of a high number of samples, (c) RNA yields representative of the microbial community, (d) RNA integrity suitable for further reverse transcription and community analysis, and (e) application of the method to diverse types of samples, is being considered a great challenge (8). In this work we tested and optimized a protocol for the simultaneous DNA/ RNA extraction from soil and rhizosphere samples which was recently published by Hurt et al. (8). Modifications of the protocol were required to ensure good RNA recovery yields after including a bead beating step and a miniaturization of the extraction procedure. To evaluate the efficiency and reproducibility of the method, the RNA and DNA extracted were analyzed by agarose gel electrophoresis and reverse transcribed RNA was used for PCR amplification of a glutamine synthetase $(g \ln A)$ gene fragment. To compare the different protocols used for RNA extraction in this study, 16S rDNA amplicons were generated from DNA and cDNA and bacterial community fingerprints were generated by means of Denaturing Gradient GelElectrophoresis (DGGE).

*Corresponding author. Mailing address: BBA, Messeweg 11/12, 38104. Braunschweig, Germany. Tel.: (+49 531) 299-3814. E-mail: k.smalla@bba.de 


\section{MATERIALS AND METHODS}

\section{Soil and rhizosphere samples}

To establish and optimize the RNA/DNA extraction procedure a soil mixture of commercially available clay substrate and sand ( $4: 1)$ mixed by sieving ( $2 \mathrm{~mm}$ mesh size) was used. The optimized protocol was applied to extract RNA/DNA from composite soil and rhizosphere samples taken from a field site at the Federal Biological Research Centre for Agriculture and Forestry (BBA) in Braunschweig which was planted with oilseed rape and strawberries. The field design, sampling and extraction of bacterial cells from soil or roots prior to DNA/RNA extraction were performed as described by Smalla et al. (13).

\section{Optimization of DNA/RNA extraction conditions}

All solutions, glassware and plastic materials used were RNase and DNase free. In order to introduce a harsh lysis step (bead beating) and to miniaturize the protocol described by Hurt et al. (8) the following modifications were used. Soil samples ( $0.5 \mathrm{~g}$ wet weight) were transferred into Bio-101 Multimix 2 matrix tubes kept on ice (as an alternative, common micro-centrifuge tubes containing $0.2 \mathrm{~g}$ glass beads can be used). After testing the addition of different ethanol, isopropanol and denaturing solution (8) concentrations to the soil before bead beating, the addition of $0.5 \mathrm{ml}$ ethanol was introduced as a new, essential step in the protocol. Tubes were agitated twice using the FastPrep FP120 bead beating system (Qbiogene, USA) at $5.5 \mathrm{~m} /$ $\mathrm{s}$ for $30 \mathrm{sec}$. Samples were kept on ice during mixing intervals. Suspensions were centrifuged at $16.000 \times \mathrm{g}$ for $5 \mathrm{~min}$ and supernatants discarded. After the addition of $1.2 \mathrm{ml}$ of extraction buffer (8) the soil slurries were mixed thoroughly and incubated at $65^{\circ} \mathrm{C}$ for $30 \mathrm{~min}$. During the incubation the tubes were inverted every ten minutes. Following a centrifugation step at $16.000 \mathrm{x} g$ for $5 \mathrm{~min}$, supernatants were poured into new tubes on ice containing $1 \mathrm{ml}$ aliquots of 24:1 chloroform-isoamyl alcohol solution. Tubes were agitated carefully and submitted to centrifugation at $16.000 \mathrm{x} g$ for $5 \mathrm{~min}$. The aqueous phase was transferred to a $2 \mathrm{ml}$ micro-centrifuge tube and nucleic acids were precipitated by incubation with isopropanol $0.6 \mathrm{vol} / \mathrm{vol}$ for at least $30 \mathrm{~min}$ at room temperature. Pellets were obtained through centrifugation at $16.000 \times \mathrm{g}$ for $20 \mathrm{~min}$, washed twice with $0.5 \mathrm{ml} 70 \%$ ice cold ethanol and air dried before resuspension in $0.2 \mathrm{ml}$ of RNase-free water. To obtain the RNA, $100 \mu \mathrm{l}$ of the extracted nucleic acids were processed with the RNeasy Mini Kit (QIAGEN, Germany) and the other $100 \mu \mathrm{l}$ aliquot was used to recover the DNA using the GENECLEAN SPIN Kit (Qbiogene, USA) according to the manufacturer's instructions.

\section{Application of the protocol}

We compared the DNA/RNA obtained with the optimized protocol from bacterial pellets recovered from soil and rhizosphere samples according to Smalla et al. (13) with RNA extracted according to the protocol by Griffiths et al. (6) and with DNA obtained directly from the bacterial fraction by means of the Bio 101 DNA extraction kit (Qbiogene, USA). Nucleic acid yields, the efficiency of RNA reverse transcription, and 16S rDNA and $g \ln A$ PCR amplification from the cDNA and DNA were compared. The composition and relative abundance of bacterial populations were compared by DGGE analysis of $16 \mathrm{~S}$ rDNA fragments amplified from DNA or cDNA obtained with the different protocols.

\section{Reverse transcription}

Purified RNA extracted from rhizosphere and soil samples was reverse transcribed with the enzyme Superscript II RNase $\mathrm{H}^{-}$reverse transcriptase (Invitrogen, Germany). Reaction mixtures $(20 \mu \mathrm{l})$ contained $50 \mathrm{mM}$ Tris- $\mathrm{HCl}(\mathrm{pH} 8.3), 75 \mathrm{mM} \mathrm{KCl}$, $3 \mathrm{mM} \mathrm{MgCl} 2,10 \mathrm{mM}$ dithiothreitol, $500 \mu \mathrm{M}$ of each deoxynucleoside triphosphate, $250 \mathrm{ng}$ of random primers, and $50 \mathrm{U}$ of Superscript II reverse transcriptase. Reactions were performed for $50 \mathrm{~min}$ at $42^{\circ} \mathrm{C}$, followed by incubation at $70^{\circ} \mathrm{C}$ for $15 \mathrm{~min}$ to inactivate the reverse transcriptase. Products were kept frozen at $-20^{\circ} \mathrm{C}$ until use.

\section{Glutamine synthetase $(g \ln A)$ PCR}

DNA and cDNA were used as templates for PCR amplification with primers GS1 (5' GAT GCC GCC GAT GTA GTA 3') and GS2 (5' AAG ACC GCG ACC TTP ATG CC 3'), resulting in a 156-bp fragment of the $g \ln A$ gene. Non reverse transcribed, purified RNA samples were used as negative controls. PCR conditions were the same as described by Hurt et al. (8).

\section{PCR-amplification of 16S RNA gene fragments and DGGE analysis}

The eubacterial-specific primers F984 and R1378 (7) were used for amplification of 16S rRNA gene fragments from DNA and cDNA samples as previously described by Heuer et al. (7). Analysis of the 16S rDNA amplicons was done by the Dcode System (Bio-Rad, Germany). Amplicons ( $10 \mathrm{ng}$ ) were applied onto polyacrylamide gels containing a 6-9\% gradient of acrylamide and a $26-58 \%$ gradient of denaturants (urea/formamide). DGGE runs were carried out in $1 \mathrm{x}$ Tris-acetate-EDTA buffer at $58^{\circ} \mathrm{C}$ and $220 \mathrm{~V}$ for $6 \mathrm{~h}$. Gels were silver stained according to Heuer et al. (7). Profiles were analyzed with the software package Gelcompar 4.0 (Applied Maths, Belgium). The program allows background subtraction and normalization of the lanes to be compared. Pearson correlation index matrices were generated and dendrograms were formed with the unweighted pair group method using arithmetic averages (UPGMA).

\section{RESULTS AND DISCUSSION}

Harsh cell lysis is crucial to obtain nucleic acids representing the microbial community in soil or rhizosphere samples (14). 
Therefore, we had included a bead beating step in the RNA/ DNA extraction protocol by Hurt et al. (8). Furthermore, to process many samples in parallel, a miniaturization of the protocol was required. However, when we applied the protocol with the modifications mentioned to our soil samples, the RNA obtained was frequently degraded. Since RNA is often preserved as ethanol precipitate, we explored the idea of adding RNA protecting substances such as ethanol, isopropanol or the denaturing solution used by Hurt et al. (8) already before breaking up the cells by means of a bead beating step. Fig. 1 shows DNA and RNA yields obtained after adding different amounts of the RNA protecting substances before cell lysis. The results showed RNA degradation when denaturing solution was added to the soil, while the addition of isopropanol or ethanol directly to 0.5 $\mathrm{g}$ of soil clearly reduced the degree of degradation. In the optimized protocol the addition of ethanol was introduced before bead beating. The optimized protocol is suitable for processing a large number of samples within a short period of time, which is a great advantage and an essential requirement for ecological studies. The integrity of the RNA is an important parameter since degraded RNA can lead to partial loss of target sites of probes or primers, which in turn results in difficulties concerning community structure analysis and hybridization purposes (1).

A comparison of DNA and RNA yields from soil and rhizosphere samples obtained with the optimized protocol and the protocol by Griffiths et al. (6) was made and is shown in Fig. 2. Our protocol resulted in good DNA yields and the presence of

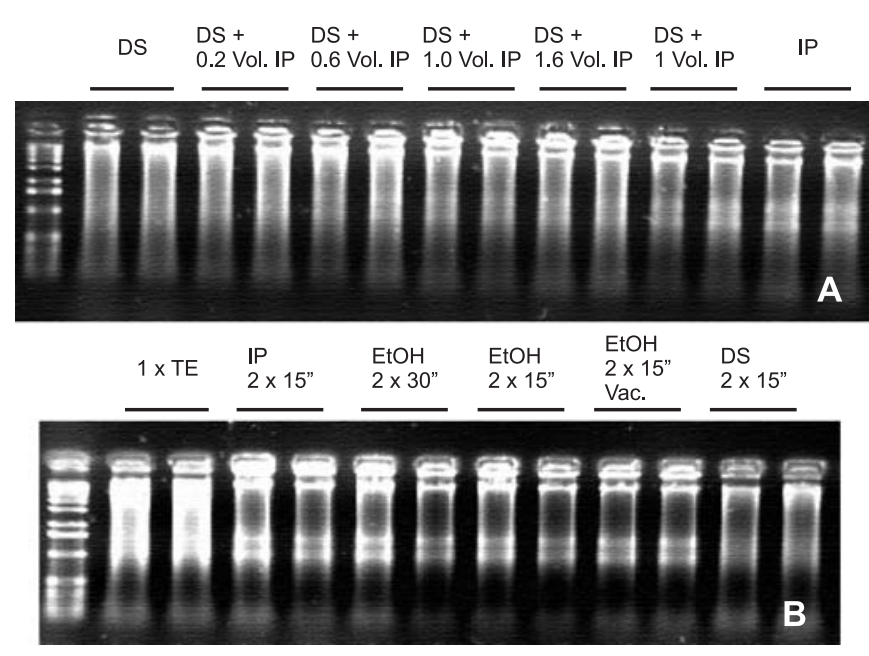

Figure 1. Nucleic acids recovered from bulk soil according to different treatments prior to cell lysis. (a) recovering efficiency according to different concentrations of isopropanol (IP) and denaturing solution (DS). (b) Comparison of ethanol (EtOH), IP, DS and Tris-EDTA buffer treatments ( $0.5 \mathrm{ml}$ of each substance) before cell lysis. Samples are shown in duplicates. Exposure times during bead-beating are shown ( 2 x 15" = two times for 15 seconds).
RNA material is clear although degradation was observed for some samples, in contrast to the results from the initial optimization (Fig. 1). The method described by Griffiths et al. (6) clearly yielded lower amounts of both DNA and RNA, as revealed by agarose gels. However, purified RNA samples could be reverse-transcribed into cDNA, which, in turn, proved to be of enough purity for further PCR amplifications, as well as the DNA extracted from both protocols. Recovering of mRNA was shown through the amplification of the $g \ln A$ gene fragment from the cDNA obtained with RNA samples. Here we show the results obtained with the optimized protocol for strawberry rhizosphere DNA, cDNA and purified RNA (negative controls) samples as an example (Fig. 3). DGGE analysis of 16S rDNA fragments revealed that equivalent profiles were observed with RNA from both methods for most of the replicates (Fig. 4a). However, for some of the replicates (e.g., rhizosphere 3) bands differing between the protocols could be identified. No separate clusters were found when analyzing the DGGE profiles with Gelcompar, even between soil and rhizosphere samples (data not shown). To find out whether the DNA-based DGGE profiles differ from those based on cDNA, the respective PCR products obtained from four soil replicates were analyzed in blocks on a DGGE gel (Fig. 5). Overall, although a few differences could be identified, the majority of the bands was detected in both profiles. Since we routinely use the commercial kit BIO101 for DNA extraction from
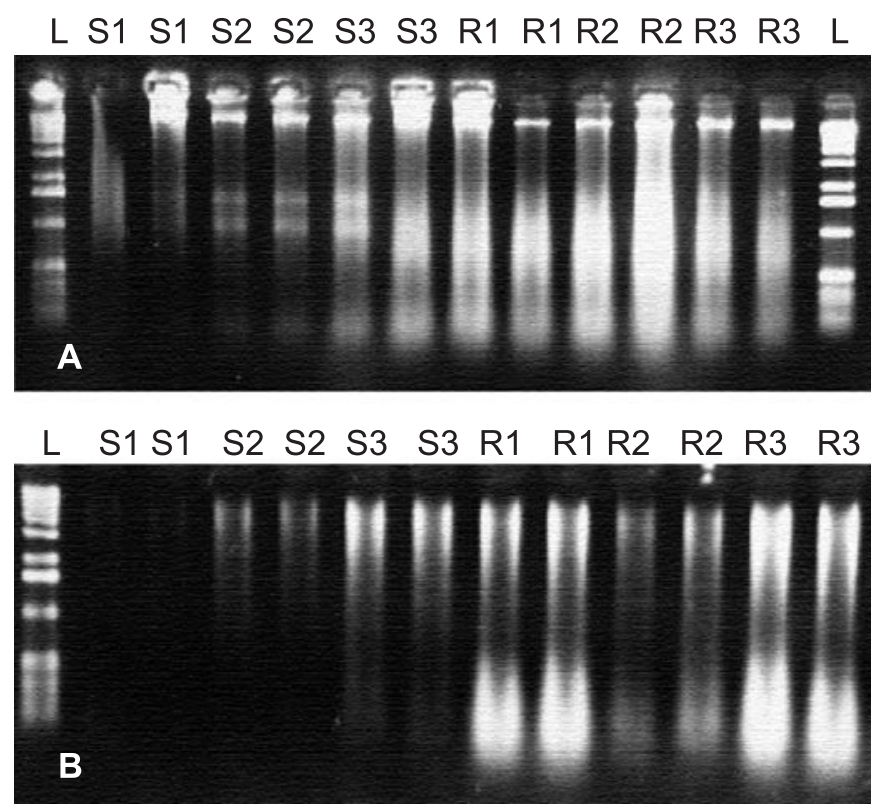

Figure 2. Ethidium bromide-stained agarose gels (1.0\%) showing DNA/RNA yields obtained for soil (S) and oilseed rape rhizosphere $(\mathrm{R})$ duplicates according to (a) the procedures described in this work and (b) Griffiths et al. (6). L - $1 \mathrm{~Kb}$ DNA Ladder. 


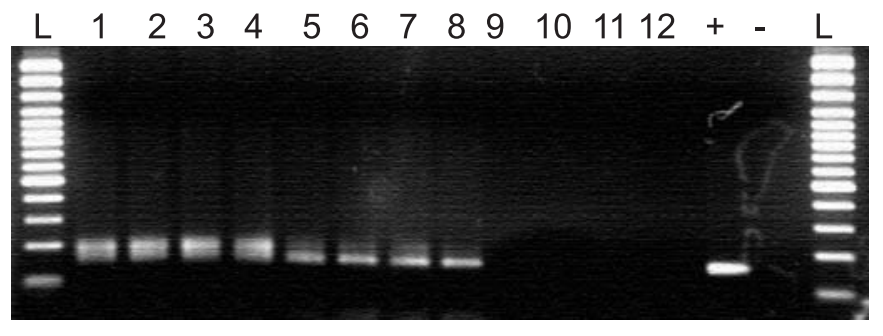

Figure 3. Amplification of the ca. $156 \mathrm{bp}$ fragment of the glutamine synthetase gene $(g \ln A)$. Products were generated by using DNA and cDNA from strawberry rhizosphere replicates. RNA was used as negative control. Agarose gel was stained with ethidium bromide. Lanes 1 to 4, DNA samples; 5 to 8, cDNA samples and 9 to 12 , RNA samples. (+) positive control, (-) negative control (no template), and (L) 100 bp DNA Ladder Plus (Gene Ruler).

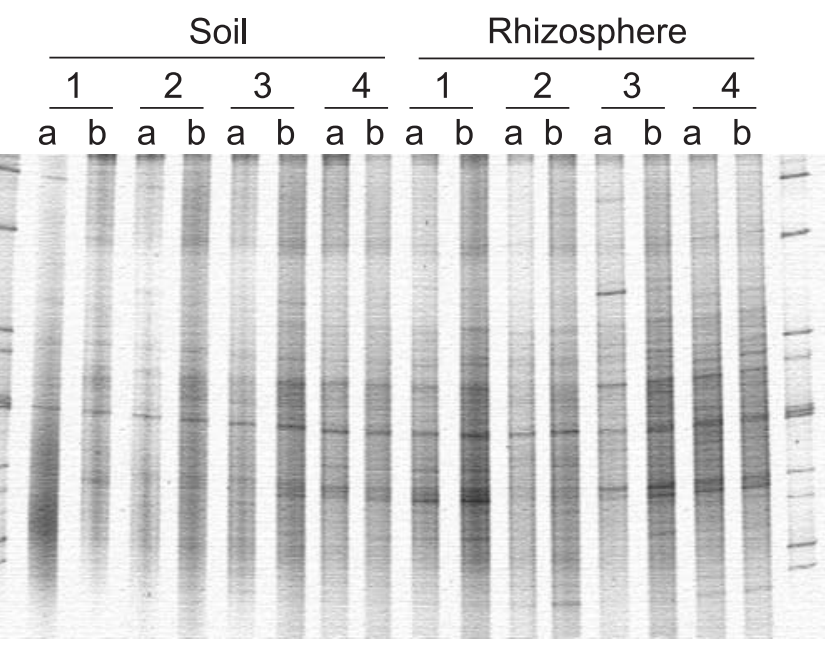

Figure 4. DGGE fingerprinting of bacterial cDNA communities from soil (S) and oilseed rape rhizosphere (R) samples by using the protocol optimized in this work (a) and the protocol described by Griffiths et al (b). Replicates were run side by side in order to allow good comparison of the profiles by eye. Lanes 1 and 14: Bacterial standard (7).

soil, we also compared the $16 \mathrm{~S}$ rDNA amplified from BIO101 soil DNA with those amplified from the DNA obtained with the optimized protocol (Fig. 5). For the DNA extraction kit one replicate was clearly less efficiently amplified and thus the DGGE lane was removed before cluster analysis. The use of the DNA extraction kit seems to allow the visualization of a higher number of bands in the gel. The same was observed for strawberry and oilseed rape rhizosphere samples (data not shown), suggesting a high DNA extraction efficiency of the kit.

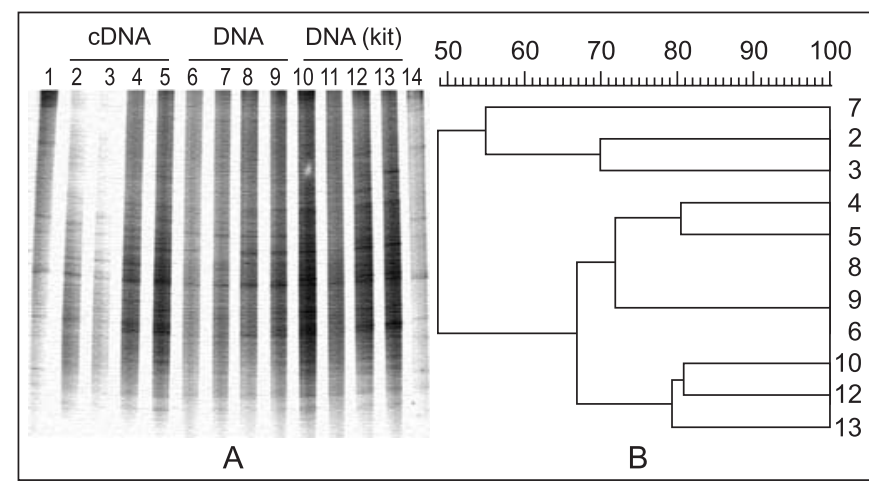

Figure 5. (a) Comparison between soil bacterial community fingerprints of $16 \mathrm{~S}$ rDNA fragments amplified from cDNA and DNA recovered with the protocol described in this work and from DNA extracted with the BIO $101 \mathrm{Kit}$ (Qbiogene, USA). Lanes 2 to 5, cDNA replicates; lanes 6 to 9, DNA replicates; lanes 10 to 13, DNA replicates (BIO 101); lanes 1 and 14, bacterial standard. (b) - Clustering of the replicates according to the matrix generated by Pearson's correlation index and grouping by UPGMA.

The protocol reported here has proven to yield nucleic acids of sufficient purity for further PCR amplification and community analysis. DGGE fingerprints of $16 \mathrm{~S}$ rDNA fragments amplified from cDNA and DNA obtained with the optimized protocol from soil and rhizosphere samples were comparable to the patterns observed for cDNA from the Griffiths protocol (6) and DNA extracted with the BIO101 kit. Hence, RNA and DNA simultaneously extracted according to the procedures described here are supposed to be representative of the naturally occurring microbial community, fulfilling the requirements needed for a suitable procedure for recovering nucleic acids from the environment (8). Further application of the method to a large variety of different soil matrices is, however, still required for adequate evaluation of its robustness.

\section{ACKNOWLEDGMENTS}

This work was funded by the Deutsche Forschungsgemeinschaft (DFG). R.C. and N.C.M.G. were financed by a fellowship of the Deutscher Akademischer Austauschdienst (DAAD). Further funding for N.C.M.G. was obtained by the EU-project QLK3-CT-2002-02068.

\section{RESUMO}

\section{Protocolo otimizado para extração simultanea de DNA e RNA de solo}

Nesse trabalho descrevemos um protocolo otimizado para extração simultânea de DNA e RNA de solo. O tratamento das 
amostras de solo com etanol e posterior agitação com partículas foi uma estratégia bem sucedida para lise das células sem degradação significativa dos ácidos nucléicos, resultando em bom rendimento de DNA e RNA íntegros. O RNA transcrito pode ser amplificado com iniciadores com alvo no fragmento do gene da glutamina sintetase (glnA). Os fragmentos 16S rDNA, tanto do DNA como do cDNA, foram amplificados e analisados por DGGE. O método foi aplicado para amostras de solo e rizosfera (morango e canola). Dois outros protocolos para extração de ácidos nucléicos de solo foram aplicados para o mesmo lote de amostras, de forma a comparar os métodos quanto à eficiência e reprodutibilidade. Os perfis de DGGE mostraram não haver diferença relevante nos padrões obtidos. O método descrito é apropriado para o processamento rápido de muitas amostras e, conseqüentemente, adequado para estudos ecológicos.

Palavras-chave: extração de RNA, ácidos nucléicos, rizosfera, comunidades microbianas

\section{REFERENCES}

1. Alm, E.W.; Stahl, D.A. Critical factors influencing the recovery and integrity of rRNA extracted from environmental samples: use of an optimized protocol to measure depth-related biomass distribution in freshwater sediments. J. Microbiol. Methods, 40:153$162,2000$.

2. Duarte, G.F.; Rosado, A.S.; Seldin, L.; Keijer-Wolters, A.C.; van Elsas, J.D. Extraction of ribosomal RNA and genomic DNA from soil for studying the diversity of the indigenous microbial community. $J$. Microbiol. Methods, 32:21-29, 1998.

3. Duineveld, B.M.; Rosado, A.S.; Van Elsas, J.D.; Van Veen, J.A. Analysis of the dynamics of bacterial communities in the rhizosphere of the Chrysanthemum via denaturing gradient gel electrophoresis and substrate utilization patterns. Appl. Environ. Microbiol., 64:49504957, 1998.

4. Felske, A.; Engelen, B.; Nübel, U; Backhaus, H. Direct ribosome isolation from soil to extract bacterial rRNA for community analysis. Appl. Environ. Microbiol., 62:4162-4167, 1996.
5. Gomes, N.C.M.; Fagbola, O.; Costa, R.; Rumjanek, N.G.; Buchner, A.; Mendonca-Hagler, L.; Smalla, K. Dynamics of fungal communities in bulk and maize rhizosphere soil in the tropics. Appl. Environ. Microbiol., 69:3758-3766, 2003.

6. Griffiths, R.I.; Whiteley, A.S.; O'Donnell, A.G.; Bailey, M.J. Rapid method for coextraction of DNA and RNA from natural environments for analysis of ribosomal DNA- and rRNA-based microbial community composition. Appl. Environ. Microbiol., 66:5488-5491, 2000.

7. Heuer, H.; Wieland, G.; Schönfeld, J.; Schönwälder, A.; Gomes, N.C.M.; Smalla, K. Bacterial community profiling using DGGE or TGGE analysis, in Environmental Molecular microbiology: Protocols and Applications (Rouchelle, P., ed.) Horizon Scientific Press, Wymondham, UK., 2001, p.177-190.

8. Hurt, R.A.; Qiu, X.; Wu, L.; Roh, Y.; Palumbo, A.V.; Tiedje, J.M.; Zhou, J. Simultaneous recovery of RNA and DNA from soils and sediments. Appl. Environ. Microbiol., 67:4495-4503, 2001.

9. Lee, D-H.; Zo, Y.-G.; Kim, S.-J. Nonradioactive method to study genetic profiles of natural bacterial communities by PCR-singlestrand conformation polymorphism. Appl. Environ. Microbiol., 62:3112-3120, 1996.

10. Liu, W.T.; Marsh, T.L.; Cheng, H.; Forney, L.J. Characterization of microbial diversity by determining terminal restriction fragment length polymorphisms of genes encoding 16S rRNA. Appl. Environ. Microbiol., 63:4516-4522, 1997.

11. Moran, M.A.; Torsvik, V.L.; Torsvik, T.; Hodson, R.E. Direct extraction and purification of rRNA for ecological studies. Appl. Environ. Microbiol., 59:915-918, 1993.

12. Muyzer, G.; de Waal, E.C.; Uitterlinden, A.G. Profiling of complex microbial populations by denaturing gradient gel electrophoresis analysis of polymerase chain reaction-amplified genes encoding for 16S rRNA. Appl. Environ. Microbiol., 59:695-700, 1993.

13. Smalla, K.; Wieland, G.; Buchner, A.; Zock, A.; Parzy, J.; Kaiser, S. Roskot, N.; Heuer, H.; Berg, G. Bulk and rhizosphere soil bacterial communities studied by denaturing gradient gel electrophoresis: plantdependent enrichment and seasonal shifts revealed. Appl. Environ. Microbiol., 67:4742-4751, 2001.

14 Van Elsas, J.D.; Smalla, K.; Tebbe, C.C. Extraction and analysis of microbial community nucleic acids from environmental matrices. In: Jansson, J.K.; van Elsas, J.D.; Bailey, M.J. (eds). Tracking geneticallyengineered microorganisms. Eurekah, Austin, Texas, 2000, p. 29-51.

15. Weinbauer, M.G.; Fritz, I.; Wenderoth, D.F.; Höfle, M.G.; Simultaneous extraction from bacterioplankton of total RNA and DNA suitable for quantitative structure and function analyses. Appl. Environ. Microbiol., 68:1082-1087, 2002. 